\title{
Role of Youth in Strengthening Parliamentary Federal Democracy in Nepal
}

Khagendra Prasai*

\begin{abstract}
Politics has become a frustrating social activity for many young people. However, there is no escape from it: the only choice in democratic society is between "good" politics and "bad" politics. The performance of "independent" media, our cultural and social norms, some constitutionals provisions, liberalism and cynicism are among those principal factors that are responsible for the alienation of you from politics. Federal structure, in the meantime, has encouraged the youth to engage in politics. In a federal-democratic society, youth needs to possess critical and deliberative mind to make politics meaningful and productive. This paper explores the roles youth can play in strengthening federal democracy in Nepal.
\end{abstract}

Key words: Democracy, federalism, constitution, participation, socialization, liberalism, critical mind.

\section{Introduction}

With the promulgation of the Constitution of Nepal in 2015 which established Nepal as a federal democratic republic brought about through countless sacrifices, many new aspirations, dreams and hopes have made an upward swing. Ideals such as prosperity, justice, equality, socialism, inclusion and development found important places in the new Constitution (Government of Nepal, 2015, p. 1 \& 27). The people became sovereign, the architect of their destiny. Parties and leaders appeared as the sole political actor, with enough power and opportunity to deliver on many good things to the nation and the people. The people, in general, and the youth became much enthusiastic and placed their high hopes on leaders and parties.

But, to our dismay, the nation has not witnessed expected changes for the better. The old problems have remained intact and the new ones have emerged. The hopes of great many people have been dashed, with the dreams of the nation and the people remaining far from materialized. People's disenchantment with the leaders, parties and governments, and democracy and federalism is growing.

This is the age of democracy. The multiparty system, despite its failure in many parts of the globe, has been publicized in a way the kind of which was unheard of. But a sizable portion of demos in many "democratic countries" does not participate in and influence the democratic process.

\footnotetext{
* Dr. Prasai has earned PhD in Philosophy from State University of New York, USA. Currently he is teaching philosophy at Tribhuvan University.
} 
The participation of youths in politics even in those countries which claim to have long experiences in democracy stands "dismally low". A report by the International Idea says: "Despite the growth in the global voter population and the number of countries that hold elections, the global average voter turnout has decreased significantly since the early 1990s" (Solijonov, 2016, p. 24).

Many people who participate in politics do so very passively and occasionally as mere voters and, they always find themselves at the receiving end. The qualitative, active and effective participation of citizens, in general, and youths, in particular, has become a rare phenomenon. Even under welfare state, as Habermas has convincingly demonstrated that citizens are converted into passive consumers and client of the state (Habermas, 1984, p. 344-52). As a result, democracy has not become the kind of thing which we had envisioned and struggled for.

With this general concern in mind, this paper argues for a case why youth should realize the importance of politics (section 2); discusses the factors that contribute to the alienation of youth from politics, and consequently, are causing the poor performance of democracy in Nepal (section 3); argues why Nepalese federal structure is conducive to the participation of youth in politics; and discuss the qualities, skills and virtues the youth need to develop to make politics and meaningfully constructive force for a just order and progress? Section 6 sums up the paper.

As per the methodology, this paper is characteristically theoretical and therefore based more on the construction of arguments and counterarguments. It does not draw directly much from primary and secondary data. It, however, makes use of those facts that are mostly incontestable in the public domain, or at the least, widely accepted by academic communities and the public alike. In short, it is an argumentative paper.

\section{Why Politics Matters}

"Politics is a dirty game." "Politics is none of my business." "What difference does politics make?" These are the comments which we, more often than not, hear from many of our youths about politics. The comments reflect their perception of, experience with, and observation of, politics. Several factors lie at the bottom of such perceptions and comments, one of them being little understanding of politics, its utility and purposes, and its significance and influence.

Now let's turn our attention to what politics is all about and why it matters. Politics can be defined as the sum of those social processes and activities which are concerned with acquisition, distribution and exercise of social power. The social power is not exercised in vacuum but in society, not in vain but to the purposes. The politics affects all spheres of our personal and public life, directly and indirectly. Take health, for 
instance. Health of a person hinges on availability of food, health facilities, environment and his own habits. All these factors are directly or indirectly influenced by the government's policies and their implementation, and, therefore, by politics. Likewise, politics has a bearing on our education, quality of life, economy and even our personal relationship. Politics affects our life whether we do it or not. But it certainly makes difference when we do it, consciously and purposefully.

Yes, of course, "Politics is a dirty game" is what trips off the tongue of most people. Politics has been played dirtily and, this has created frustration in the large chunk of our population, keeping them at bay from it. The point which I want to make here clear is that the remedy lies not in distancing from the politics but in playing it fairly. We do not stop playing football just because some players play it unfairly. The choice is not between "yes politics" and "no politics", the choice is between "dirty politics" and "healthy politics." The fate of any nation or society primarily depends on how politics is done. Therefore, the question is not: Should one engage in politics or not? The question rather is: How can we do healthy politics? How can politics be made a healthy game, a constructive collective effort and a positive force for just order and progressive change? To make politics a healthy game, a constructive force for social order and progress, we must prevent it from going into the hands of stupid, villainous and wicked people. Therefore, good and intelligent people should keep interest and involve in politics.

In democracy, it is the citizens who form, control and run government. The politics and government are on citizens' hand. If government is site and embodiment of demo's legitimate power, theoretically, it cannot be conceived as the means of suppression but an instrument by which to regulate and coordinate the actions of citizens toward achieving the defined goals and translating social and political ideals into a living reality. The principle "of the people, by the people and for the people" (Lincoln, 1863) stands meaningful only when all citizens participate in the political process consciously, and in the capacity of real actors. Whereas, in undemocratic system, a small section of the society, often known as elite, runs government, therefore, citizens, at large, are not required to do politics. In those societies, politics is something to be done by the elite on the people. The people do not have active and conscious role. But democracy requires all the citizens to participate in politics which only, in turn, can ensure democratization of the state and society.

Freedom and equality are the hallmarks of democracy, worth striving for. The future of freedom and equality, their possibility of being transformed into a living reality, largely, depends on what kind of government we constitute-democratic or nondemocratic. Long ago in $340 \mathrm{BC}$, Aristotle rightly put: "If liberty and equality, as is 
thought by some, are chiefly to be found in democracy, they will be attained when all persons alike share in the government to the utmost" (Aristotle, 1992).

Some people highlight the importance of technical and professional education to youths for the development of nation. But they, at the same time, forget that advancement of science and technology is impossible without the committed, dedicated, intelligent and visionary leadership. I argue that a nation can solve her problems and progress only when she has good leaders in power. Therefore, it stands to reason to say that a good deal of intelligent people should be in political leadership.

However, the demand for de-politicization of schools and school children is also popular.. It is argued that youths and students should be kept away from politics, education should be freed of politics, and development should be set apart from politics. These arguments reflect their gross misunderstanding about politics and government. They perceive politics as inherently bad, antagonistic to development and progress of a person and nation and as a barrier to study. These are the seriously mistaken ideas. As a matter of fact, education, development, freedom, all these are political agenda. There is no denying that our politics and governments have performed far less satisfactory than, and even contrary to, the expectations of people. But remedy lies not in keeping youths away from politics but in encouraging them in healthy and constructive politics. This is the only way to fight the evils of politics and to make it a positive force for just order and progressive change. Edmund Burke is worth quoting here: "The only thing necessary for the triumph of evil is for good men to do nothing" (Edmund Burke, 1780).

In democratic society, every citizen has a role in the capacity of an actor. Here, we are concerned with the participation and role of youths in politics. Why youths? The history is the witness to the fact that youths have played the most decisive role in many political movements and revolutions. The youth have demonstrated their discontents with the rotten ideas and system and have always stood for ideals and changes, now progressive, now revolutionary. The youth with its vitality and thirst for newness and change have played a powerful and decisive role in the making of human history here and there. The Nepali youths are not exception to this. In our history, youths constituted the strength and vitality of all movements and organizations. The role played by some portion of our youth population in different times of our history deserves appreciation and respect. But some of the youths have remained passive, while more others have been used as reactionary forces to impede the changes in society. A good deal of our contemporary youths have suffered from these syndromes and failed to emerge as a powerful agent of social change.

Let me point out some problems with the contemporary youth. Firstly, a chunk of our youth population is not interested in grave political, social and national issues. They 
perceive politics as a dirty game and keep away from it. Despite being educated, this portion has failed to understand politics and its importance in the life of a person and a nation.

Secondly, the other section which consists of educated and uneducated youths is actively engaged in politics. Whether in peaceful democratic movement or rebellion, youths have formed the major basis of strength. But, the problem with them is that they have not participated in politics as actor and master. They are very keen in obeying orders of their leaders in the name of discipline and hardly dare to question their leaders, however stupid and undemocratic their ideas and actions may be. They have usually, though not always, acted as blind supporters of their leaders and the party. Hardly have they acted as informed, wakeful, equal, dignified and responsible member in their party. They are good at toeing the line of their leaders without any serious look into it. Many of them are not acquainted with what they have borrowed or accepted. Something is there, they accept it but they don't know what it is. The discussion and examination are a far-off thing. They became the objects of manipulation, mobilization and use at the hands of others. As a result, the youths have, at least, not yet been able to prevent the deterioration of the parties which were developed with their hard work, toil, blood and sacrifice. They have become a mere spectator, borrower and follower - the qualities which are suitable only to autocratic system. In critical and important moments of our national life, they have failed to act responsibly and effectively and have demonstrated their inability to exert powerful and significant influence. This holds true of the majority of youths in our political parties. However, it is plausible to hold that there are some youths who, despite possessing fundamental qualities required for good leadership, have not been able to come to the front and take the lead because their wavelength does not match with that of the majority in the party.

\section{Barriers to Politicization of Youth}

As we have already discussed, the future of democracy depends on the kind of politics done in the country. The nation which does not assign active role to youths loses the base and vitality of its life. Emphasizing the importance of youth in society in general, Kofi Annan remarks: “... no one is born a good citizen; no nation is born a democracy. Rather, both are processes that continue to evolve over a lifetime. Young people must be included from birth. A society that cuts itself off from its youth severs its lifeline; it is condemned to bleed to death" (Annan, 1998).1

The wisdom lies in involving the youth in constructive politics and not in keeping them away from it. It is important to identify those factors which have contributed to the de-politicization of youths. Some of the factors are discussed below. 
Performance of Parties, Leaders and Governments

In order to understand the alienation of a good deal of youths from politics, we need to examine the performance of parties, leaders, government. A gloomy picture of our recent federal democratic experience is that the performance of the leaders, parties and governments has not adequately triggered the enthusiasm of youth in favor of active political engagement. That politics is a dirty game, a game of tricks, conspiracy and treachery intended mainly for the self-aggrandizement has made home in their mind. For them, politics means the tricks played by politicians against their rivals within and between the parties in order to rise up and secure their position. Most of the time and energy were and are wasted in plotting and conspiring against each other. One can scarcely see the leaders discussing important and far-reaching social, national and international issues. The inter and intra party rivalry form the major subject matters of speeches, writings and discourse. Though "development" has occupied almost all political and governmental discourse, highly important development-related issues such as land reforms, industrialization, education, capital accumulation etc. rarely found their place in the same. The parties, leaders and governments have yet to effect significant changes in the country. The dreams and aspirations of the people do not seem to be materializing. Many new problems are adding up to an alarming scale and intensity. The youths with new dreams, aspirations and enthusiasm is unable to perceive politics as collective efforts to materialize their dreams. In this way, parties failed not only in attracting new youths but also in maintaining faiths and trust of their youths on them.

The parties systematically discourage free and open discussion and the leaders do not entertain questions. They want the cadres to accept their decisions without question, obey their orders and become submissive to them. The democratic political culture has not taken roots and flourished, as a result of which parties are losing their vitality and democratic character. The leaders and parties have not demonstrated and proved rationality of their ideas and decisions in many issues. The performance of parties and different organs of the state is falling far below our expectations, and, in most cases, are contradictory to democratic principles and standards. These things erode hopes and faith placed on parties and leaders. The youths who were and are enthusiastic and hopeful in the new political system, are increasingly being skeptical. In a nutshell, the increasing failure and inability of our parties, leaders and governments to make politics a positive and constructive force, to bring about expected changes, to keep alive the faith and hope of the people and to show good performance is largely responsible for repelling youth from politics.

\section{Media}

In this age of ours, media has emerged as very powerful agent of socialization. It has even been demonstrated how socialization in the age of ours is the effect of media (Genner and Suss, 2016). In addition to this, in democratic society media has a share in 
governance and therefore is recognized as The Fourth Estate. Normatively, it is expected to play a vital role in promoting democratic values, educating and informing citizens, facilitating and carrying out free and open public debates, raising the concerns and consciousness of people in social, national and constitutional issues. In the last few decades, media has grown in quantity as evident in the numbers of TV, radio, print and online media but its corresponding qualitative growth compatible with normative demand of democracy and constitutionalism is still far below the satisfactory level. The performance of media needs to be examined.

The Nepalese media have given little importance and place to such themes that could be conducive to transforming our young generation into informed, wakeful and responsible citizenry such as issues of economics, regional and global cooperation, environments and ecology. A sizable section of literate and educated youths is lost in trivial, frivolous and even harmful things because by giving much importance and value to these things, media have shaped their likings. The media have done very little to attract the attention of youths and raise their concern on serious and weighty social and political issues that matters locally, nationally and globally.

Most of the political converge and news consists of rivalry and antagonism between leaders, and parties. The media cover such rivalry and unhealthy contentions as if they were what constitute politics. The news and coverage are about those leaders who are mostly in power. They always put "big" leaders in their priority Hardly has media done anything to promote capable, intelligent and honest individuals of the parties. Therefore, the people, in general, and party members, in particular, are less likely to know that political alternatives exist for them.

Our media have done very little to promote social sciences. A research shows that social science finds very little space and importance in media (Prasai, 2004). The development of social sciences is very conducive to the strengthening of democracy. Social sciences provide us with facts, theories and perspectives about social realities, issues and problems, which help us build our ideas and opinions on a scientific base. Social sciences, in fact, go a long way in contributing a good share to framing policies and plans. They help us resolve "anarchy of opinions" and reach a consensus on issueswhich is vital to decision making.

But, there are media that have promoted superstition, dogmatism and fatalistic beliefs by giving considerable space or time to horoscopy and the likes. Some media persons argue that media must take into account the likings and interest of people. But, should media give what youths like or should they help the youths understand what their 'real' needs are? Should the Fourth Estate promote scientific consciousness or should 
they promote superstition? Should media be not committed to the fundamental principles of democracy and act accordingly?

\section{Cultural and Social Barrier}

Some of our habits, customs and practices discourage the youths to be active, thoughtful and conscious members of our society. A man below twenty five is not considered capable of wisdom and reason and is often shrugged off as belonging to Gadha Pachhisi. When a boy or a girl criticizes ideas, opinions and viewpoints of elder members of his or her family, teachers and other seniors, the answer they receive is "Khukuri Bhanda Karda Lagne." If a youngster disagrees with his or her senior and presents better arguments, he or she is harassed as: Don't be Mr. Know, I have worn out more bhotos than you.

Fortunate enough, though such tendency is ingrained in our tradition, it is rapidly fading away. However, despite this, youths are not considered eligible for higher positions in political parties. Therefore, a man and woman of forty assuming leadership position in parties and government is still not conceivable in Nepal.

It is common that teachers, parents and elder members of family do no discuss politics and other national issues with the younger members. Hardly do parents want their children to keep interest in politics. Most of our teachers and parents hold the view that students should not be interested in and do politics. If children and students want to discuss politics, they are told that it is not their business and matter of concern. They warn the children and students that doing politics disturbs and harms their study. Some parents think that their children are not worth talking politics with. As a result, interest and inquisitiveness of our children do not get opportunity to develop.

\section{Constitutional and Legal Barrier}

Some of our constitutional and legal provisions, to some extent, are responsible for low participation of youths in politics as active and conscious actor. In our legal provisions, a person is eligible for citizenship at 16 , is entitled to voting at 18 . But he or she should be 21 to stand in local election and 25 to stand in provincial and federal elections (Government of Nepal, 2016). The incompatibility in these provisions needs examining. A person is eligible to vote means he or she is eligible to elect. He or she is eligible to elect means he or she is capable enough to make judgment and assessment about candidates, parties and policies. But, how is it that a person who possesses abilities and qualities to make such judgments is not eligible for being elected? Such provision of eligibility makes them feel that they are of secondary political importance and that they are not qualified to take on responsibilities for their society and nation. A good deal of this "less" citizens not qualified for being elected to public offices may not feel the strong urge to do politics as actor and master. He or she perceives politics to be done on him or her by others, seniors and elders. 


\section{Liberalism and Cynicism}

Liberalism is not a new ideology, but in the last two decades, it has come with such force and frenzy the kind of which was not known and experienced before. Libertarianism, an extreme form of liberalism, following John Locke, gives highest value to individual liberty and rights and views state as the "foremost violator of liberty" (Scott and Marshall, 2009, p. 416). The weakness inherent in liberalism is that it could not envision a democratic state which could create and maintain conditions necessary for the realization of liberty. Moreover, liberalists ignore the importance of society on human life and make too much of individualism. They have gone so far to say that "there are only individuals but no society." The question of priority of society over individual and vice versa is no longer meaningful. As convincingly argued for in sociology, "individual and society are the two aspects of the same reality, and therefore, are inseparable from each other" (MacIver and Page, 1949, p. 43). Liberalism, by emphasizing the individual and ignoring the society, has sowed the seeds of enmity between these two and thereby has given rise to and fueled, now latent and now manifest, antagonism.

Indoctrinated with and guided by liberalism, some of our youths prefer to make individual efforts for the fulfillment of individual interests. This kind of tendency is opposed to the principle of democracy since democratic politics is a process of making collective efforts and action for the collective interests and well-being. Therefore, individual with liberalist indoctrination has little faith on collectivism. He or she believes in "by oneself for oneself". The problem is social but he or she seeks personal and individualistic solutions which are extremely limited in their influence and effectiveness. In their individualistic efforts, a few may reach success but the fate of the many people cannot be changed this way.

Some youths have developed cynical tendency and attitudes. Cynics view people's efforts as being guided by selfish motives and intentions. They dismiss that a person can have good and noble intentions in his thoughts and actions and view politics as selfish play even if there are good leaders making good action and producing desired results. Cynicism prevents a person from recognizing and appreciating good deeds of others. It prevents them from working together with others in cooperation and, therefore, from joining democratic and healthy politics.

\section{Federalism and Motivation for Political Engagement}

Despite a variety of barriers which I discussed above, recent political and constitutional development in Nepal, namely, institution of federal structure along with the three tiers of governments has provided opportunity and encouragement to the youth for political engagement. Federal structure has permeated government throughout Nepali 
society and thereby, has created opportunity to a significantly larger number of people for political participation. The province and local levels government structure provides platform not only for youth participation at these levels but also opportunity for building of leadership competence for higher level of politics. These levels provide youth opportunity through which political leadership matures. Basically, these levels are more accessible to youths.

At these levels, youths have opportunity to connect politics with their local needs, aspiration, problems and solutions and make politics a local social phenomenon that matters and through which they can make a big difference. This, arguably, is the most beautiful aspect of federalism.

\section{Youth, Leadership and Federal Democracy}

The vigor and the vitality, in themselves, are not the positive and constructive forces and can be used and manipulated by others for the fulfillment of their parochial interests and for the destructive purposes if the possessors of these qualities are not conscious of what they are doing and what is being done on them. The mere participation of youths in politics does not make qualitative and desired difference in the present situation. What is needed is the conscious and active participation as actor and master of politics. Therefore, the youths should stop being "active follower", spectator, believer, devotee and "honest and loyal soldier". The new youth should be cautious not to repeat the same mistakes committed before.

The beauty of democracy, I believe, lies not in being the rule with the consent of a majority but in promoting free and open discussions and deliberation. This creates opportunities for several ideas to come to the floor. This kind of democracy requires citizens to possess and develop certain civic qualities. He or she must be informed, studious, open and critical minded, and deliberative. As an open-minded person, he or she should listen to the arguments of others and accept if such arguments are logical and fact-based. As a critical-minded person, he or she should not readily accept but examine ideas and arguments scientifically. He or she should always be prepared to discuss and deliberate any issues and should use reasoning and arguments if he or she wishes to persuade others. But most of our political disputes have been settled through bargaining. The bargaining strategy is undemocratic because free discussions and debates are not keys to agreements. In the bargaining, the decisions are accepted not because the parties are convinced that they are optimal and rational but because of "resources and power relations involved." The "new youth" will have to make the politics and democracy vibrant and lively through free and scientific deliberation which alone can keep the soul of democracy alive. 
Democracy, constitution and federal structure of the state are not self-functioning and do not automatically work. The functioning of any democracy depends on the qualities of leaders or political actors. The mal-functioning of our democracy in the past can be attributed to incompetence and inability of the leaders. The nation has suffered much from the lack of quality leadership. The nation is in pressing need of leadership for local and national governments, for different levels of party organization and for different public agencies. The youths can fulfill this need by taking on the leadership responsibility and by building and supporting the competent, visionary, and honest leaders. Only informed, critical and active youths can make and build the kind of leadership our nation needs. Such leaders help the youths develop those qualities which are required of them in democratic system. Only the studious and informed youths can understand the vision and plans of leaders and can participate meaningfully, whole-heartedly and effectively.

Moreover, democracy is not just about individual freedom and choice. Rather, it is about exercising freedom and choice collectively. Individuals cannot exercise their freedom and rights in isolation from each other; they require group or collectivity. Democracy is a system in which individuals' interest are transformed into the collective interests through a rigorous process of political participations. In this sense, in democracy, interests of individuals and society at large do not stand antagonistic to each other. Slightly differently, in a genuine democratic system, individuals, as Marx has pointed out, strive for a society "in which the conditions for the development of each will be the conditions for the development of all" (Marx \& Engels, 1848, p. 27).

\section{Conclusion}

A sizable portion of youth is increasingly distancing from politic, with hardly any interests in it. The important thing that the youth need to understand is that the remedy lies not in escaping from politics but in doing it in a healthy way. The choice is not between "yes politics" and "no politics" but between "dirty politics" and "healthy politics". Several factors have contributed to de-politicization of youths, chief of which are: (a) performance of parties, leaders and governments; (b) media (c) some of our cultural and social norms and practices; (d) some constitutional and legal provisions; and (e) liberalism and cynicism. Despite these barriers, federalism has brought about a condition which has provided an opportunity to a large number of youth for political engagement in locally, provincially and nationally.

The youths have a very crucial and vibrant role to play in federal democratic system. The vitality of youth is not a positive force in itself, but there exists a danger of it being manipulated and used by others if he or she is not conscious. The youths need to develop some qualities which are required of citizens in democratic society. They need to be studious, thoughtful, critical minded and deliberative to make politics a positive force of change as expected and desired by the people. 


\section{References}

Annan, Kofi. (1998). "Press release SG/SM/6670" Retrieved from https://www.un.org/press/en/1998/19980810.sgsm6670.html

Aristotle. (1992). Politics. Penguine Groups: London (Revised Edition)

Dahal, Dev Raj., (2006). Civil society groups in Nepal. UNDP: Kathmandu. Retreived from ,

http://citeseerx.ist.psu.edu/viewdoc/download?doi=10.1.1.729.3967\&rep=rep1\&type=pdf

Genner, Sarah and Daniel Suss. (2016). "Socialization as media effect" http://sarah.genner.cc/uploads/5/1/4/1/51412037/socialization_as_media_effect.p $\underline{\mathrm{df}}$

Government of Nepal. (2016). Pradeshshabha nirwachan ain 2073. Author: Kathmandu

Government of Nepal. (2016). The constitution of Nepal 2015. Kathmandu: Author

Government of Nepal. (2016).. Pratinidhishabha nirwachan ain 2073. Author: Kathmandu

Government of Nepal. (2016).. Sthaniya nirwachan ain 2073. Author: Kathmandu

Habermas, Jürgen. (1984). The theory of communicative action volume II, lifeworld and system: A critique of functionalist reason. (Trans. Thomas McCarthy). Beacon Press: Boston

His Majesty Government of Nepal. (1990). The constitution of the kingdom of Nepal 2047 (1990). HMGN: Nepal

Lincoln, Abraham. (1863). "Gettysburg speech" Retrieved from http:// www.abrahamlincolnonline.org/lincoln/speeches/gettysburg.htm

MacIver, R. M. and Charles, H. Page. (1949). Society: an introductory analysis. Macmillan India Limited: New Delhi

Marx and Engels. (1848). The communist manifesto. (Republished in 201)Retrieved from: https://www.marxists.org/archive/marx/works/download/pdf/Manifesto.pdf

Prasai, Khagendra. (2004). "The role and the performance of media in nepal", Kathamandu School of Law: Kathmandu

Scott, John and Gordon Marshall. (2009). Oxford dictionary of sociology (Third Edition). Oxford University Press: Oxford

Solijonov, Abdurashid. (2016). Voter turnout trends around the world. International IDEA: Stockholm. Retrieved from https://www.idea.int/sites/default/files/publications/voter-turnout-trends-aroundthe-world.pdf 